Visualizing Objects, Places, and Spaces: A Digital Project Handbook

\title{
e-xiliad@s Project
}

\section{Lidia Bocanegra Barbecho}

Published on: Feb 14, 2021

License: Creative Commons Attribution-NonCommercial 4.0 International License (CC-BYNC 4.0). 


\section{Team}

The project is administrated by the senior researcher, Digital Humanities and Digital History specialist, Lidia Bocanegra Barbecho, who had the idea for the project and the participatory strategy. The project was developed at the technical level by Maurizio Toscano, who specializes in information architecture and DH.

\section{Project URL \& Files}

Website: https://exiliadosrepublicanos.info/

Poster: "Ten years recovering the memory of republican exile with citizen collaboration. The results of E-xiliad@s Project: a perspective from Digital Humanities and Digital Public History." 


\section{TEN YEARS RECOVERING THE MEMORY OF REPUBLICAN EXILE WITH CITIZEN COLLABORATION. THE RESULTS OF E-XILIAD@S PROJECT: A PERSPECTIVE FROM DIGITAL HUMANITIES AND DIGITAL PUBLIC HISTORY}

\section{THE PROJECT AIM}

E-xiliad@s is a crowdsourcing research project about the Spanish republican exile, financially supported by the Spanish Ministry of Labour and Immigration in 2009 and by the Ministry of Employment and Social Security in 2011, through the Dirección Genera de Migraciones. The aim is to collect unpublished data, online, about the anonymous Spanish Republican exile, mainly for the period from 1939 to 1959 Franco regime, related to social, public and contemporary history and a strong focus on gender, hence the name "e-xiliad@s".

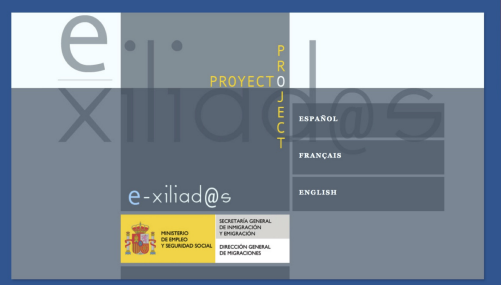

WWW.EXILIADOSREPUBLICANOS.INFO

\section{THE COMMITMENT}

E-xiliad@s collaborates to recover the memory of the republican exile through Open Data, with the consent of the users; at the same time, it is responsible to communicate to the society, with scientific rigor, the topics of exile and return, through the methodology of Digital Public History.

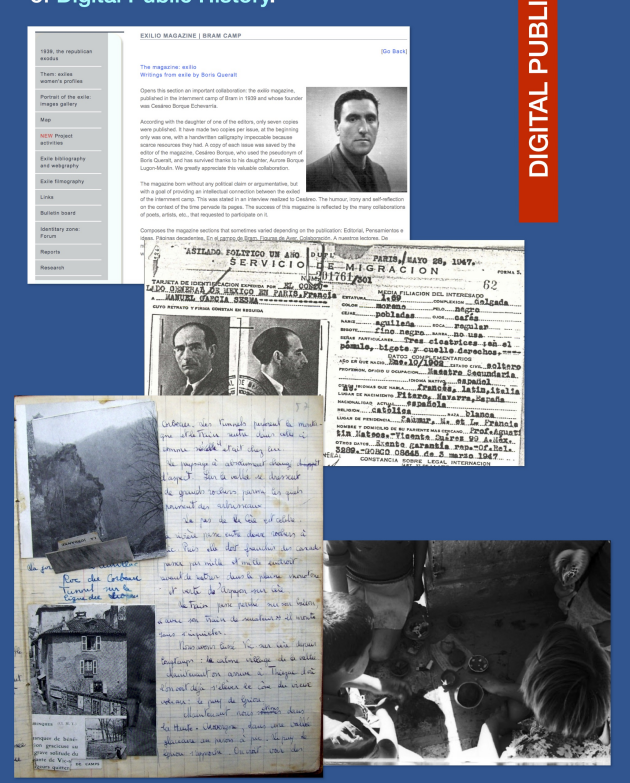

\section{CO-CREATION METHODOLOGY}


The unpublished data are provided by users who, after registration, compile a series of questions collected in a web form created ad hoc, called Ficha del exiliado in Spanish or Exile Record in English. It has a series of questions, mandatory or not, some of them with a free text field and others with closed lists. The questions respect a chronological order; the objective is to stimulate the family memory of those who fill it.

Visibility - Multilingual project (Spanish / French / English). Countries of highest audience: Spain, France, Mexico, USA, Argentina, Great Britain, Chile, Colombia, Puerto Rico. For more than $\mathbf{1 0}$ years, the project appears in the top queries, in the topic of the Republican exile, in the main search engines.

Search Engine Optimisation (SEO) - code without errors, internal metatags, URL, etc. Large amount of published content - creation of new Exile Records and new sections. Use of the project's social networks (Facebook and Twitter), with more than $1.5 \mathrm{k}$ followers, to generate and disseminate new content.

Reciprocal exchange. Using the system "you give me, I offer you" helps to expand the project, generating greater confidence to new users that want to deposit their memory in it. How the system works?

a) Collection of information through the internal web form (you give me);

b) Services offered by the project (I offer you): publication of the information received in related sections, with prior consent; historical advice via email; bulletin board; dissemination of information through project social media; creation of informative sections about exile: biographies, geolocated map, biblio/webography, travelogues.

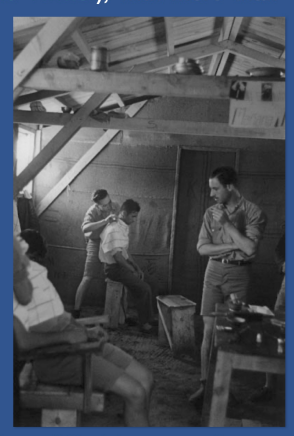

User friendly Web layout - Easy-to-use and professional layout that incorporates ecommerce web design knowledge: positioning of information and images strategically, writing by paragraphs.

\section{E-XILIAD@S RESULTS}

Since 2010, e-xiliad@s has published approximately 200 records of anonymous exiles and compiled about 500 files among images, scanned official documents, old newspaper articles, memoirs, poems, sound documents (interviews). More than $80 \%$ of the records are public, which shows a wide availability of users internationally to share and recover the memory of republican exile. The project has more than 1.500 followers in its social networks and nearly 45.000 visits to the project's website every year, becoming today one of the reference projects at academic and international level about the Republican exile.

\begin{tabular}{|llll:}
\hline EXILE RECORDS & TOTAL: 200 & PUBLISHED: $81 \%$ & UNPUBLISHED: $19 \%$ \\
\hline FILES & TOTAL: 485 & PUBLISHED: $69 \%$ & UNPUBLISHED: $31 \%$ \\
\hline ANNOUNCEMENTS & TOTAL: 65 & COMMENTS: 64 & \\
\hline IMAGE GALLERIES & TOTAL: 21 & & \\
\hline WEB SECTIONS & TOTAL: 89 & & \\
WEB VISITS & TOTAL: 507.068 & USERS: 160.578 & \\
\hline FOLLOWERS & TOTAL: 1528 & FACEBOOK: 924 & TWITTER: 604 \\
\hline
\end{tabular}

Award for the best participation / presence

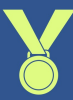

in social media 2019 - Asociación de Hu-

manidades Digitales Hispánicas (Premios HDH 2020).

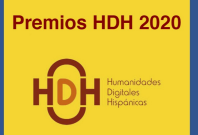

DH2020. CARREFFOURS / INTERSECTIONS. 


\section{Project Abstract}

The website e-xiliad@s is a crowdsourcing research project on the ppanish republican exile. The aim is to collect and share online information on the Spanish republican exile from the period 1936-39 to the first stages of Franco's regime, with an approach focused on digital humanities, and social history in its modern and gender-related implications. We have collected 200 profiles of exiled people, including more than 500 supporting media files and other archival records.

E-xiliad@s is born digital and uses digital participatory strategies in different phases. The core of the project is the creation of an exile record that corresponds to an exiled person who, with the prior consent of the user offering the data (digitised objects and/or digital data), is published in a specific section ( $\underline{\text { biographies). }}$. The project has developed a participatory strategy based on "you give me, I give you" widely published in scientific literature and in open access. 

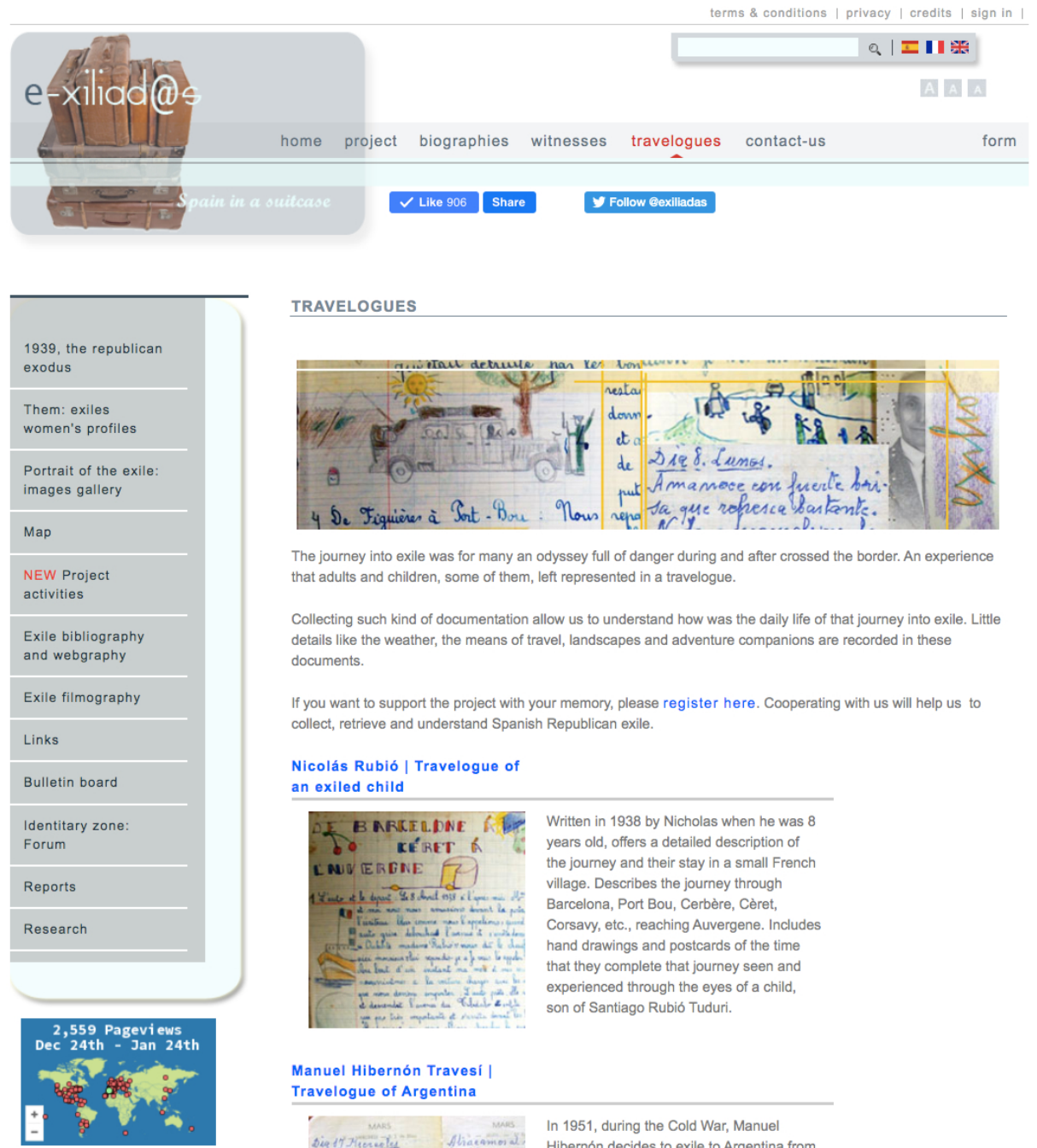

TRAVELOGUES

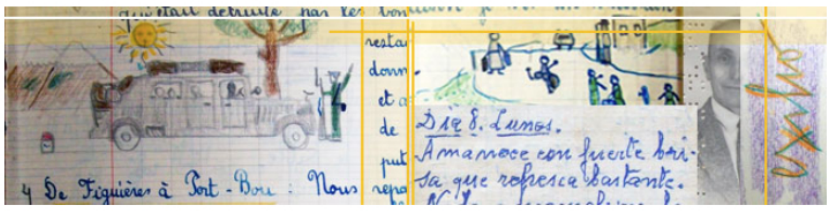

The journey into exile was for many an odyssey full of danger during and after crossed the border. An experience that adults and children, some of them, left represented in a travelogue.

Collecting such kind of documentation allow us to understand how was the daily life of that journey into exile. Little details like the weather, the means of travel, landscapes and adventure companions are recorded in these documents.

you want to support the project with your memory, please register here. Cooperating with us will help us to collect, retrieve and understand Spanish Republican exile.

Nicolás Rubió | Travelogue of an exiled child

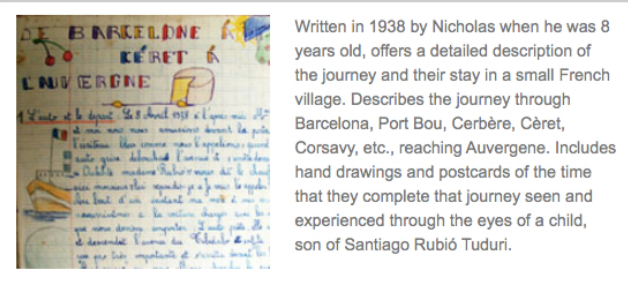

Manuel Hibernón Travesí |

Travelogue of Argentina

\begin{tabular}{l|l} 
In 1951, during the Cold War, Manuel \\
Higernón decides to exile to Argentina from
\end{tabular}

\begin{tabular}{l}
\hline home | project | map | reports | form | links | site-map | \\
xhtml | css $\quad$ Contact Webmaster
\end{tabular}

Travelogues 


\begin{tabular}{l}
\hline $\begin{array}{l}\text { 1939, the republican } \\
\text { exodus }\end{array}$ \\
\hline $\begin{array}{l}\text { Them: exiles } \\
\text { women's profiles }\end{array}$ \\
\hline $\begin{array}{l}\text { Portrait of the exile: } \\
\text { images gallery }\end{array}$ \\
\hline Map \\
\hline $\begin{array}{l}\text { NEW Project } \\
\text { activities }\end{array}$ \\
\hline $\begin{array}{l}\text { Exile bibliography } \\
\text { and webgraphy }\end{array}$ \\
\hline Exile filmography \\
\hline Links \\
\hline Bulletin board \\
\hline Identitary zone: \\
\hline Forum \\
\hline Reports \\
\hline
\end{tabular}

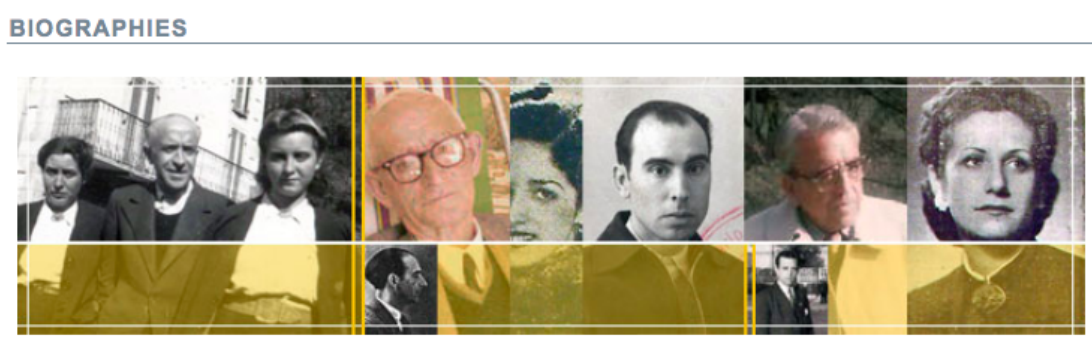

The records listed in this section are those collected through the Form. Only the records with a policy of public data sharing has been published. They represent a synthetic frame of the individual stories of exile, structured in a schematic way to stimulate a synoptic reading.

The records are presented in the original language used by its author, ie French, English or Spanish.

\begin{tabular}{|c|c|c|c|c|c|}
\hline $\begin{array}{l}\text { First } \\
\text { Surname }\end{array}$ & $\begin{array}{l}\text { Second } \\
\text { Surname }\end{array}$ & Name & $\begin{array}{l}\text { Town of } \\
\text { birth }\end{array}$ & $\begin{array}{l}\text { Town of } \\
\text { Destination }\end{array}$ & $\begin{array}{l}\text { Year of } \\
\text { exile }\end{array}$ \\
\hline Artía & & Bienabé & Irún & & \\
\hline Agut & Armer & Enriqueta & $\begin{array}{l}\text { Castellón de la } \\
\text { Plana }\end{array}$ & Veracruz & 1939 \\
\hline Aranoa & & Juan & Bilbao & Buenos Aires & \\
\hline Arteta & Errasti & Aurelio & Bilbao & & \\
\hline Azarloza & Urquiza & Bingen & Amorebieta & Burdeos & 1937 \\
\hline
\end{tabular}

Biographies 


\section{|| The magazine: exilio}

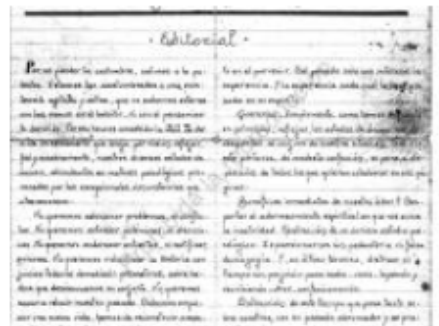

Exilio - Volumen 1



Exilio - Volumen 4

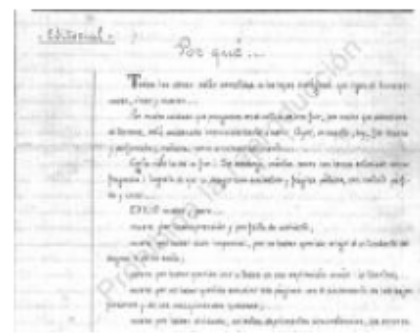

Exilio - Volumen 7

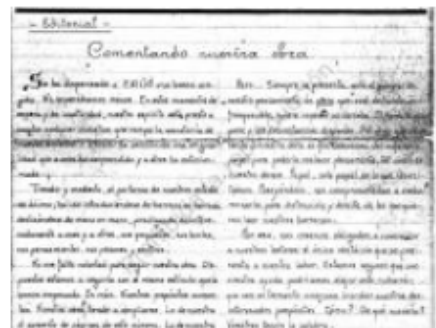

Exilio - Volumen 2



Exilio - Volumen 5

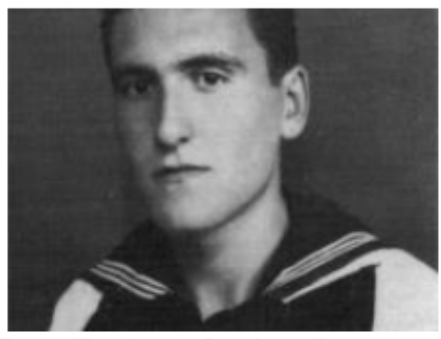

Fotos/Escritos - Cesáreo Borque -

Editor revista exilio

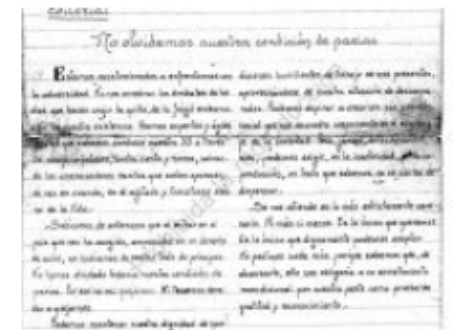

Exilio - Volumen 3

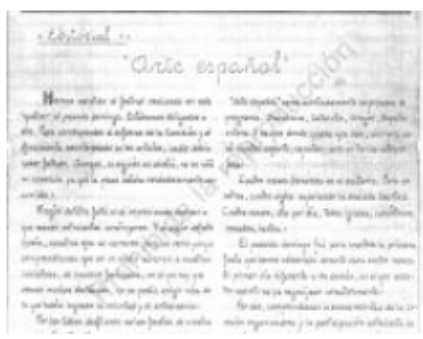

Exilio - Volumen 6

Exilio Magazine. Camp Bram 


\section{How to create a record - Demo}

\section{Time Needed}

When did you begin this project? When did you complete this project?

Time Span: February 1, 2010 - present

Length: $10+$ years

\section{Outcomes}

What is the outcome of the project?

A crowdsourcing research project that uses a website to collect unpublished, internationally dispersed data from the anonymous Spanish republican exile.

\section{Resources}

What tools, resources, programs, or equipment did you use for this project?

The website was built in 2010 with what was, back then, one of the most complete software solution to create a multilingual and community oriented website: Drupal 6. The platform aged well in the last decade, requiring only periodical updates of the core code and the few modules used. Drupal 6 reached 
end-of-life official support in February 2016. Since then, we joined the Drupal 6 Long-Term Support initiative. A complete upgrade of the IT infrastructure is planned, but not scheduled.

The website initial development, subsequent improvements as well as on-going support and maintenance has been carried out by Maurizio Toscano.

\section{Funding}

Please describe any costs incurred for this project, and (if relevant) how you secured funding for these costs.

In total, the project has received approximately $€ 15,000.00$, not counting annual costs for server and domain hosting and IT maintenance. The project received financial support from the Ministry of Labour and Immigration in 2009 and the Ministry of Employment and Social Security in 2011.

\section{Workflow}

Please give an overview of the workflow or process you followed to execute this project, including time estimates where possible.

The argument of the Republican exile has a very international character due to the fact that there are a great number of documents and photographs of exiles in many countries where these people were located. Only a stand alone data collection project such as e-xiliad@s could collect, with the help of citizens, all these sources and store them in a relational database.

Applying citizen science strategies, the project is born and executed from the academic environment, where the data provided by the citizens is supervised and the project is maintained. To make the project work, a communication strategy is implemented to disseminate the initiative and call for public participation. The project uses social networks dealing with Republican exile or related topics, e.g. Spanish Civil War, World War II, Holocaust, etc., in order to gain new users and communicate the results of the project to a specific target audience: relatives of exile, specialists, etc.

The submissions are collected via internal form, connected with the database and supervised by the admin of the project. To access the form the user first need to sign in by choosing a username and providing an e-mail address. The project will then send to the user an e-mail with the necessary instructions to complete the registration. This way the project guarantee the user privacy and security to all the data he/she add.

The form consists of a list of general questions, some of which are mandatory, exclusively referring to a single woman, man or child. It also offers open fields and the possibility to upload images and 
digitised text. Whether the user were directly or indirectly involved in the exile, he/she can contribute anyway, as long as he/she provide all the personal details required.

The records listed in the Biographies section are those collected through the Form. Only the records with a policy of public data sharing has been published. They represent a synthetic frame of the individual stories of exile, structured in a schematic way to stimulate a synoptic reading. The records are presented in the original language used by its author, ie French, English or Spanish.

The data and digitised objects obtained are made open access, subject to the user's consent, and are used to inform about the Republican exile, to produce publications and to recover the memory of the Republican exile in general. It is worth noting that the project is innovative, as some people have obtained, thanks toe-xiliad@s, information about relatives who disappeared because of the war.

\section{Challenges \& Opportunities}

What, if anything, changed between beginning your project and its current/final form?

Depending on the specified data and their quality (scanned photographs, certificates, unpublished memories) the quantity, and the historical interest of the person, or the object (unpublished handwritten magazine, travel journals, etc.) the project created new ad hoc sections according with the quality and amount of the data gathered. Furthermore, based on the demand for information from users, the project created sections such as the bulletin board where users can request information about missing exiles. The project has also been strengthening its social networks (Facebook and Twitter), which now have more than $1.6 \mathrm{~K}$ followers. This strengthens the participatory nature of the research project and helps create a community and identity of exile online and helps gather more data for the project.

It should be noted that the project has received in 2020, by the prestigious Association Humanidades Digitales Hispánicas ( $\underline{\mathrm{HDH}}$ ), the Award for the Best participation/presence in social media 2019; coinciding with the 80th anniversary of the Spanish Republican exile. 


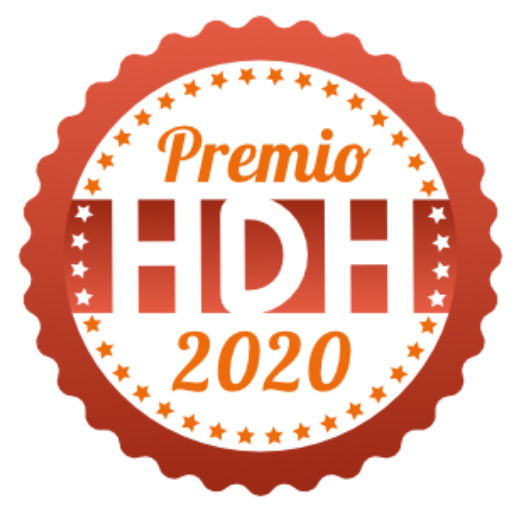

Is there anything specific you wish you had known when beginning your project that might help other people to know?

The importance of carrying out a good communication strategy at a social and scientific level in specialised channels (congresses and international seminars) and stakeholder places (clubs, associations) and to publish always in open access. This highlights the important role of social networks and their participatory and informative role in the project.

\section{Next Steps}

Do you have any plans to follow up on this project or work on something similar in the future?

Yes. It is a live project, which works mostly autonomously in certain periods, without any communication boosting and, in others, receives a boost at the communicative level from the Administrator and other researchers, collaborators of the initiative, in order to collect data. It is currently an internationally recognized project, not only among academics who cite and use the project in their classrooms and scientific papers; but also among the public for its role in documenting Spanish historical memory. The last five years the e-xiliad@s admin has been invited and participated in national (UC3M, UVA, UAL, UMA) and international (ADHO, HDH, Associazione Italiana di Public History, UNAM) seminars and conferences. For 2020, we plan to study the possibility of upgrading the platform to Backdrop $\underline{\text { CMS. }}$.

\section{Publications \& Presentations}

Bocanegra Barbecho, Lidia. (2015). 'Cada día atrasamos el reloj un cuarto de hora para llegar con la hora americana'. Diario de viaje hacia el exilio. In América: Cultura visual y relaciones artísticas (pp. 
363-372). Granada, España: Universidad de Granada. http://doi.org/10.5281/zenodo.1182943.

Lidia Bocanegra-Barbecho. (2017). Identidad y pertenencia del exilio republicano español en la red internet: generando memoria y cultura a través de las plataformas sociales digitales y el uso del Open Data. In Decolonizando Identidades. Pertenencia y Rechazo de/desde el Sur Global. Granada, Spain: Instituto de Migraciones, Universidad de Granada. http://doi.org/10.5281/zenodo.1312999.

Bocanegra Barbecho, Lidia. (2015). La web 2.0 y el estudio del exilio republicano español: El análisis de la movilidad social y el retorno a través del proyecto e-xiliad@s. In "Otras voces, otros ámbitos": Los sujetos y su entorno. Nuevas perspectivas de la historia sociocultural. (pp. 59-65). Valencia, España: Universidad de Valencia; Asociación de Historia Contemporánea.

http://doi.org/10.5281/zenodo.1182456.

Bocanegra Barbecho, Lidia. (2014). Memoria, exilio republicano e historia digital: El Proyecto exiliad@s. Quiroga, revista del patrimonio iberoamericano, 6, 61-63.

http://doi.org/10.5281/zenodo.1182357.

Bocanegra Barbecho, Lidia. (2014). Proyecto e-xiliad@s. Recuperando fuentes inéditas acerca del exiliado republicano anónimo a través de la web 2.0. 10.13140/RG.2.2.31463.19360.

Bocanegra Barbecho, Lidia. (2019). Public participation to recover and communicate the memory of the Spanish republican exile through Digital Public History and Open Data: the e-xiliad@s project. $\underline{10.13140 / R G .2 .2 .33979 .77605 . ~}$

Bocanegra Barbecho, Lidia. (2015). Revista Exilio. Campo de Bram. In Actas del Congreso Posguerras: 75 aniversario del fin de la Guerra Cvil española. Madrid, España: Editorial Pablo Iglesias. http://doi.org/10.5281/zenodo.1182839.

Bocanegra Barbecho, Lidia, \& Yolanda Guasch Marí. (2015). El semanario Exilio y los intelectuales del campo de Bram, 1939. Laberintos: revista de estudios sobre los exilios culturales españoles, 17, 6-27. http://doi.org/10.5281/zenodo.1182305.

Bocanegra Barbecho, Lidia, \& Toscano, Maurizio. (2015). El exilio republicano español: Estudio y recuperación de la memoria a través de la web 2.0. Nuevo enfoque metodológico con el proyecto exiliad@s. Migraciones \& exilios, 15, 113-136. http://doi.org/10.5281/zenodo.1182238.

Bocanegra Barbecho, Lidia \& Toscano, Maurizio. (2011). Informe 2010: Proyecto e-xiliad@s. $\underline{10.13140 / R G .2 .2 .10763 .75043 .}$.

Bocanegra Barbecho, Lidia, \& Toscano, Maurizio. (2016). The Spanish Republican Exile: Identity, Belonging and Memory in the Digital World. In Cultural Heritage in a Changing World (pp. 237-253). 
Springer International Publishing. http://doi.org/10.5281/zenodo.1182426.

Bocanegra Barbecho, L., Toscano, M., \& Delgado Anés, L. (2017). Co-creación, participación y redes sociales para hacer historia. Ciencia con y para la sociedad. Historia Y Comunicación Social, 22(2), 325346. https://doi.org/10.5209/HICS.57847. 